\title{
ON THE USE OF EXTENDED PLATE THEORIES OF VEKUA - AMOSOV TYPE FOR WAVE DISPERSION PROBLEMS
}

\author{
Sergey I. Zhavoronok \\ Institute of Applied Mechanics of Russian Academy of Sciences, Moscow, RUSSIA \\ Moscow Aviation Institute (National Research University) - MAI, Moscow, RUSSIA
}

\begin{abstract}
The extended plate theory of I.N. Vekua - A.A. Amosov type is constructed on the background of the dimensional reduction approach and the Lagrangian variational formalism of analytical dynamics. The proposed theory allows one to obtain the hierarchy of refined plate models of different orders and to satisfy the boundary conditions on plates' faces exactly by introducing the corresponding constraint equations into the Lagrangian model of two-dimensional continuum. The normal wave dispersion in an elastic layer is considered, the convergence of the two-dimensional solutions to the exact one is studied for the locking phase frequencies, the dimensionless stress distributions across the thickness of a layer are shown.
\end{abstract}

Keywords: hierarchical modeling of plates, dimensional reduction, analytical continuum dynamics, constrained Lagrangian systems, elastic layer, wave dispersion

\section{О ПРИМЕНЕНИИ РАСШИРЕННЫХ ТЕОРИЙ ПЛАСТИН И.Н. ВЕКУА - А.А. АМОСОВА К ЗАДАЧАМ О ДИСПЕРСИИ ВОЛН}

\section{С.И. Жаворонок}

Институт прикладной механики Российской Академии наук, г. Москва, РОССИЯ

Московский авиационный институт (национальный исследовательский университет), г. Москва, РОССИЯ

\begin{abstract}
Аннотация: Расширенная теория пластин И.Н. Векуа - А.А. Амосова построена на базе метода пространственной редукции задачи механики деформируемого твердого тела и Лагранжева вариационного формализма аналитической динамики континуальных систем. Предложенная общая теория позволяет получить иерархическую систему моделей пластин различных порядков и притом точно удовлетворить краевым условиям на лицевых поверхностях, вводя соответствующие краевым условиям уравнения связей в Лагранжеву формулировку модели двумерного континуума. Рассмотрена задача о дисперсии нормальных волн в упругом слое, изучена сходимость последовательности решений двумерных задач к точному решению трехмерной задачи теории упругости по частотам запирания распространяющихся мод, приведены безразмерные распределения компонентов тензора напряжения, соответствующие собственным функциям, по толщине слоя.
\end{abstract}

Ключевые слова: иерархические модели пластин, редукция пространственной размерности, аналитическая динамика континуума, Лагранжевы системы со связями, слой упругий,

нормальных волн дисперсия

\section{INTRODUCTION}

An accurate and reliable modeling of highfrequency and wave dynamics of various thinwalled structures requires refined shell and plate models [1] accounting for higher-order degrees of freedom and of transverse normal strains [2] besides the translation and rotation of midsurface's points and the transverse shear. Indeed, essentially three-dimensional stress and strain states were found even in homogeneous isotropic plates [3, 4] and conical shells [5]; such a strain state with boundary layers appearing near the faces could be properly 
described by at least fourth-order polynomial approximation of displacement field [3] even for a thin plate. Thus, various traditional models of shear-deformable shells and plates fail in the case of high-frequency dynamics while the refined models based on special function expansions [4] or power series expansions [5] may be quite efficient. Moreover threedimensional field distributions should be accounted for laminated structures $[2,6,7]$ due to the effects of anisotropy and weak transverse stiffness. The detail survey of refined theories for laminated structures is presented in [8] by Carrera who proposed the "Carrera Unified Formulation" of refined shell models [7].

Another topical problem that needs for higher order shell and plate modeling consists in the modeling of dynamics of functionally graded structures with high heterogeneity across their thickness [9]. The known exact solutions obtained for such structures primarily in statics (e. g. see [10]) could be useful as appropriate reference solutions. It has to be noted that only a few exact solutions were obtained for free vibration problems for graded plates [11]. Thus, reliable approximate models are strictly required; the higher-order shear theories accounting for the transverse normal strain were used [12, 13], including non-polynomial based ones [14]. On the other hand, the proper choice of assumption-based plate model for reliable modeling of high frequency dynamics could become too complex. Thus, the power series expansion [5, 15, 16], generalized Fourier expansions [17], or sampling surfaces approach [18] resulting in full hierarches of twodimensional models may be efficient alternatives in mechanics of heterogeneous thinwalled structures. Let us also note that the hierarchical approach could be very useful for wave dispersion problems where the use of different plate theories should be well-founded [19]. Such an approach based on the use of Legendre polynomials as expansion functions was developed in [20, 21]. This method results in the classical spectral problem statement; it has shown its reliability and simplicity and was further used for Lamb wave dispersion problem in graded plates [22], moreover its state-space formalism was developed recently [23]. Thus, the hierarchical modeling could be also efficient in such problems for heterogeneous thin-walled structures as boundary resonances [24] or edge waves analysis [25-27] where three-dimensional elasticity solutions or higher-order asymptotic approximations may become too complex.

On the other hand, the general dimensional reduction approach based on the generalized Fourier series results in the one of most general shell theories proposed by I.N. Vekua [28]. Its efficiency in various transient dynamics problems for shells was shown, for instance, in [29]. The further development of the hierarchical theory of shells of Vekua type was proposed by A.A. Amosov [30]; in particular the exact dependency of the metrics on the normal coordinate was taken into account. The Amosov's formalism [31] is based on the Galerkin method and on the tensor algebra of linear operators in Hilbert spaces; such a formulation make it possible, among other things, to use powerful computer algebra systems to construct higher-order models of shells of variable thickness and curvature and allows one the automation level close to the finite element modeling. Several other versions of the Vekua's approach were also proposed recently (e. g. see [32-34]).

The Amosov's shell theory results in the set of various models of two-dimensional Lagrangian systems in terms of the analytical dynamics of continua. Indeed, the continuum system can be defined on a two-dimensional manifold within a set of field variables and the Lagrangian density; the type of a theory depends on the definition of the field variables. In particular, the use of expansion factors of the threedimensional displacement field with respect to the orthogonal function system of normal coordinate as field variables leads to the classical higher-order shell theory [28-34]. As well Legendre polynomials as trigonometric expansion functions could be used under the same formalism; in other word the theory [31] 
secures the covariance of the governing equations with respect to the expansion system. The further development consists in the biorthogonal expansion of the displacement vector; it allows the introduction of finite element, or finite layer discretization similar to [18] into the unified formulation of the shell theory of A.A. Amosov's type [35].

The higher-order plate models obtained in terms of the variational formalism [35] were validated on the background of the well-known Rayleigh-Lamb problem of wave dispersion in a plane elastic layer [36]. The satisfying convergence of approximate solutions given by plate models to the exact one [36] was shown for phase frequencies [37, 39] and for normal waveforms [38-42].

It must be noted nevertheless that the so-called "elementary" theory [42] allows one to satisfy the boundary conditions on the faces of a plate only approximately as a result of the convergence of a sequence of two-dimensional solutions $[31,43]$, therefore the reflection condition on the face of a layer cannot be secured for all computed wave forms. This drawback can be eliminated in "extended" higher-order theories; the earliest one was based on the use of series residuals as supplementary variables [28]. The analytical dynamics formalism offer another possibility. Indeed, the boundary conditions shifted from the faces onto the base surface become constraint equations for the Lagrangian system [44, 45]. Thus, the dynamic equations can be derived by means of the Lagrange multipliers method [44, 45] that allows one to obtain asymptotically consistent low-order models [46, 47]. On the other hand, the spectral problem of the wave dispersion is can be solved using the approach [48]; the use of this method and the accuracy of extended higher-order plate models is shown below.

\section{BASICS OF THE EXTENDED PLATE THEORY OF N-TH ORDER}

Let us consider a plate as a three-dimensional body of thickness $2 h$, bounded by faces $S_{ \pm}$and a lateral surface $S_{B}$, and let its two-dimensional model be defined on the manifold $S$, corresponding to the mid-plane and furnished by the curvilinear coordinates

$$
\xi^{\alpha} \in D_{\xi} \subseteq \square^{2}, \alpha=1,2
$$

[35, 46, 49]. A Lagrangian continuum system on $S$ can be defined within the configuration manifold $\Omega_{N}$, the set of field variables $u_{\alpha}^{(k)}$, $u_{3}^{(k)}$ being the biorthogonal expansion factors for the displacement $\mathbf{u}$ with respect to the system $p_{(k)}(\zeta), p^{(k)}(\zeta)[35,46]$,

$$
\left(p_{(k)}, p^{(m)}\right)_{1}=\delta_{(k)}^{(m)}
$$

$\mathbf{u}\left(t, \xi^{\alpha}, \zeta\right) \approx\left(u_{\alpha}^{(k)} \mathbf{r}^{\alpha}+u_{3}^{(k)} \mathbf{n}\right) p_{(k)}(\zeta), k=\overline{0, N} ;$

$u_{\alpha}^{(k)}=\left(u_{\alpha}, p^{(k)}\right)_{1} \equiv \int_{-1}^{1} u_{\alpha}\left(t, \xi^{\alpha}, \zeta\right) p^{(k)}(\zeta) d \zeta, \ldots$

here $\zeta \in[-1,1]$ denotes the dimensionless normal coordinate. The surface Lagrangian densitiy can be written as follows [49]:

$$
\begin{gathered}
\mathcal{L}_{\mathrm{S}}\left(u_{\alpha}^{(k)}, u_{3}^{(k)}, \dot{u}_{\alpha}^{(k)}, \dot{u}_{3}^{(k)}, \bar{\nabla}_{\beta} u_{\alpha}^{(k)}, \bar{\nabla}_{\beta} u_{3}^{(k)}\right)= \\
=\frac{1}{2} \rho_{(k)}^{(m)}\left(\dot{u}_{(m)}^{\alpha} \dot{u}_{\alpha}^{(k)}+\dot{u}_{(m)}^{3} \dot{u}_{3}^{(k)}\right)+F_{(k)}^{i} u_{i}^{(k)}- \\
-\frac{1}{2}\left(C_{(k m)}^{\alpha \beta \gamma \delta} \bar{\nabla}_{\gamma} u_{\delta}^{(m)}+C_{(k m)}^{\alpha \beta 3} u_{3}^{(m)}\right) \bar{\nabla}_{\beta} u_{\alpha}^{(k)}- \\
-\frac{1}{2}\left(C_{(k m)}^{3 \beta \gamma} \bar{\nabla}_{\gamma} u_{3}^{(m)}+C_{(k m)}^{3 \beta \gamma} u_{\gamma}^{(m)}\right) \bar{\nabla}_{\beta} u_{3}^{(k)}- \\
-\frac{1}{2} h^{-1}\left(C_{(k m)}^{33 \gamma \delta} \bar{\nabla}_{\gamma} u_{\delta}^{(m)}+C_{(k m)}^{333} u_{3}^{(m)}\right) \bar{D}_{(n \sqsupset)}^{((k)} u_{3}^{(n)}- \\
-\frac{1}{2} h^{-1}\left(C_{(k m)}^{\alpha 3 \gamma 3} \bar{\nabla}_{\gamma} u_{3}^{(m)}+C_{(k m)}^{\alpha 3 \gamma} u_{\gamma}^{(m)}\right) \bar{D}_{(n)}^{(k)} u_{\alpha}^{(n)} ;
\end{gathered}
$$

while the contour density is represented as

$$
\mathcal{L}_{\partial \mathrm{S}}\left(u_{\alpha}^{(k)}, u_{3}^{(k)}\right)=q_{B(k)}^{\alpha} u_{\alpha}^{(k)}+q_{B(k)}^{\alpha} u_{\alpha}^{(k)} .
$$

Here $\rho_{(k)}^{(m)}, D_{(n)}^{(k)}, C_{(k m)}^{\alpha \beta \gamma \delta}, C_{(k m)}^{33 \gamma \delta}, C_{(k m)}^{\alpha 3 \gamma 3}, C_{(k m)}^{\alpha \beta 3}$, $C_{(\mathrm{km})}^{3 \beta \gamma}, C_{(\mathrm{km})}^{333}, \ldots$ are linear operators $[31,35,43]$ : 


$$
\begin{aligned}
& \rho_{(k)}^{(m)}=\left(\rho p_{(k)}, p^{(m)}\right)_{1} ; \quad D_{(n \dashv)}^{(\urcorner k)}=\left(\frac{d}{d \zeta} p_{(n)}, p^{(k)}\right)_{1} ; \\
& C_{(k m)}^{\alpha \beta 3}=h^{-1} D_{(k \rrbracket)}^{(\curvearrowleft n)} C_{(n m)}^{\alpha \beta 33} ; \quad C_{(k m)}^{3 \beta \gamma}=h^{-1} D_{(k \sqsubseteq)}^{(\unrhd n)} C_{(n m)}^{3 \beta 3 \gamma} ; \\
& C_{(k m)}^{333}=h^{-1} D_{(k\rceil)}^{(\llcorner n)} C_{(n m)}^{3333} ; \\
& C_{(k m)}^{\alpha \beta \gamma \delta}=\left(C^{\alpha \beta \gamma \delta} p_{(k)}, p_{(m)}\right), \ldots
\end{aligned}
$$

The following constraint equations follow from the boundary conditions on $S_{ \pm}[44-46]$ :

$$
\begin{gathered}
C_{ \pm(k)}^{i \alpha \beta} \bar{\nabla}_{\beta} u_{\alpha}^{(k)}+C_{ \pm(k)}^{i \beta 3} \bar{\nabla}_{\beta} u_{3}^{(k)}+ \\
+h^{-1} D_{(m \cdot)}^{(\cdot k)}\left(C_{ \pm(k)}^{i 3 \alpha} u_{\alpha}^{(m)}+C_{ \pm(k)}^{i 33} u_{3}^{(m)}\right)=q_{ \pm}^{i} ; \\
C_{ \pm(k)}^{i \beta j}=\left.C^{i 3 j \beta}\right|_{\zeta= \pm 1} \mathrm{p}_{(k)}( \pm 1) .
\end{gathered}
$$

Thus, the plate model is defined as a twodimensional continuum within the field variables $u_{\alpha}^{(k)}, u_{3}^{(k)}$ the Lagrangian densities (1.1), (1.2) and the constraints (1.3). The appropriate equations of dynamics could be obtained as generalized Lagrange equations of the second kind [44, 45] by means of Lagrange multiplier method. They coinside with the "elementary" theory [35] if the constraints (1.3) are neglected:

$$
\begin{aligned}
& \rho_{(k)}^{(m)} \ddot{u}_{(m)}^{\alpha}=\bar{\nabla}_{\beta} \sigma_{(k)}^{\alpha \beta}-h^{-1} D_{(k \cdot)}^{(\cdot m)} \sigma_{(m)}^{\alpha 3}+F_{(k)}^{\alpha} ; \\
& \rho_{(k)}^{(m)} \ddot{u}_{(m)}^{3}=\bar{\nabla}_{\beta} \sigma_{(k)}^{3 \beta}-h^{-1} D_{(k \cdot)}^{(\cdot m)} \sigma_{(m)}^{33}+F_{(k)}^{3} ;
\end{aligned}
$$

The problem statement is closed by the boundary conditions (1.5) on the contour $\partial S$

$$
\begin{aligned}
& \left.\left(\sigma_{(k)}^{\alpha \beta} v_{\beta}-q_{B(k)}^{\alpha}\right) \delta u_{\alpha}^{(k)}\right|_{S_{B}}=0 ; \\
& \left.\left(\sigma_{(k)}^{3 \beta} v_{\beta}-q_{B(k)}^{3}\right) \delta u_{3}^{(k)}\right|_{S_{B}}=0
\end{aligned}
$$

and the initial conditions (1.6):

$$
\begin{aligned}
& \left.u_{\alpha}^{(k)}\right|_{t=t_{0}}=U_{\alpha}^{(k)} ;\left.u_{3}^{(k)}\right|_{t=t_{0}}=U_{3}^{(k)} ; \\
& \left.\dot{u}_{\alpha}^{(k)}\right|_{t=t_{0}}=V_{\alpha}^{(k)} ;\left.\dot{u}_{3}^{(k)}\right|_{t=t_{0}}=V_{3}^{(k)} .
\end{aligned}
$$

\section{STATEMENT OF THE WAVE DISPERSION PROBLEM FOR THE EXTENDED PLATE THEORY}

Let us consider hence a plane isotropic layer:

$$
\begin{gathered}
C_{(k m)}^{\alpha \beta \gamma \delta}=G_{(k m)}\left\lfloor\lambda a^{\alpha \beta} a^{\gamma \delta}+\mu\left(a^{\alpha \gamma} a^{\beta \delta}+a^{\alpha \delta} a^{\beta \gamma}\right)\right\rfloor ; \\
C_{(k m)}^{3333}=G_{(k m)}(\lambda+2 \mu) ; \quad C_{(k m)}^{\alpha 3 \beta 3}=G_{(k m)} \mu a^{\alpha \beta} ; \\
C_{(k m)}^{\alpha \beta 33}=G_{(k m)} \lambda a^{\alpha \beta} ; \quad G_{(k m)}=\left(p_{(k)}, p_{(m)}\right)_{1} .
\end{gathered}
$$

Let the wave propagate along the axis $O x_{1}$ of the Cartesian frame and let us introduce the following dimensionless variables:

$$
\begin{gathered}
\xi=x_{1} h^{-1} ; \quad \zeta=x_{2} h^{-1} ; \quad \tau=t c_{2} h^{-1} ; \\
\tilde{u}_{\alpha \beta}^{(k)}=u_{\alpha}^{(k)} h^{-1} ; \quad \tilde{\sigma}_{\alpha \beta}^{(k)}=\left(\rho c_{2}^{2}\right)^{-1} \sigma_{\alpha \beta}^{(k)}, \\
c_{2}=\mu \rho^{-1}
\end{gathered}
$$

is the shear wave velocity. As a result, we obtain the following dimensionless dynamic equations for the Nth order theory:

$$
\begin{aligned}
& \partial_{\tau}^{2} u_{1}^{(k)}=\beta^{-2} \partial_{\xi}^{2} u_{1}^{(k)}+D_{(n \beth)}^{(k)} \bar{D}_{(m \sqsupset)}^{(\curvearrowleft n)} u_{1}^{(m)}- \\
& -\left[D_{(\cdot m)}^{(k \cdot)}-\left(\beta^{-2}-2\right) \bar{D}_{(m \sqsupset)}^{(k k)}\right] u_{2}^{(m)} ; \\
& \partial_{\tau}^{2} u_{2}^{(k)}=\partial_{\xi}^{2} u_{2}^{(k)}+\beta^{-2} D_{(n\urcorner)}^{(\urcorner k)} \bar{D}_{(m \sqsupset)}^{(n)} u_{2}^{(m)}- \\
& -\left[\left(\beta^{-2}-2\right) D_{(m \sqsupset)}^{(k k)}-\bar{D}_{(m \sqsubset)}^{(k k)}\right] u_{2}^{(m)}, \\
& \beta^{2}=\left(c_{2} / c_{1}\right)^{2}=(1-2 v) /(2-2 v) \text {, } \\
& c_{1}=(\lambda+2 \mu) \rho^{-1}
\end{aligned}
$$

is the bulk wave velocity. The dimensionless constraint equations corresponding to (1.3) can be written as

$$
\begin{gathered}
\left\lfloor\left(\beta^{-2}-2\right) \partial_{\xi} u_{1}^{(k)}+\beta^{-2} \bar{D}_{(n \beth)}^{(k k)} u_{3}^{(n)}\right\rfloor p_{(k)}^{ \pm}=0 ; \\
\left(\bar{D}_{(n \dashv)}^{(k)} u_{1}^{(n)}+\partial_{1} u_{3}^{(k)}\right) p_{(k)}^{ \pm}=0 \\
p_{(k)}^{ \pm}=p_{(k)}( \pm 1),
\end{gathered}
$$


the sign "+" corresponds to the upper face and the "-" to the lower one; therefore we have two pairs of constraint equations on both faces.

Let us consider normal waves, i. e.

$$
\begin{gathered}
u_{\alpha}^{(k)}=U_{\alpha}^{(k)} \exp [i(\kappa \xi-\omega \tau)], \\
\kappa=k h
\end{gathered}
$$

is the dimensionless wavenumber and

$$
\omega=\Omega h / c_{2}
$$

is the dimensionless phase frequency. Substituting (1.10) into (1.8) we obtain the spectral problem (1.11) for the linear operator A given by (1.12) (see [37-42]):

$$
\begin{gathered}
\left(\mathbf{A}-\omega^{2} \mathbf{I}\right) \cdot \mathbf{U}=0, \quad \mathbf{U}=\left(U_{1}^{(m)} U_{2}^{(m)}\right), \\
\mathbf{A}_{(2 N+2) \times(2 N+2)}=\left(\begin{array}{cc}
\mathbf{A}_{11} & \mathbf{A}_{12} \\
\mathbf{A}_{21} & \mathbf{A}_{22}
\end{array}\right) ; \\
\left(A_{(m)}^{(k)}\right)_{11}=4\left(1-\beta^{2}\right) \kappa^{2} \delta_{(m)}^{(k)}+D_{(\cdot \cdot)}^{(k \cdot)} \bar{D}_{(\cdot m)}^{(n \cdot)} ; \\
\left(A_{(m)}^{(k)}\right)_{12}=i \kappa\left[D_{(\cdot m)}^{(k \cdot)}-2\left(1-2 \beta^{2}\right) \bar{D}_{(\cdot m)}^{(k \cdot)}\right] ; \\
\left(A_{(m)}^{(k)}\right)_{21}=i \kappa\left[2\left(1-2 \beta^{2}\right) D_{(\cdot m)}^{(k \cdot)}-\bar{D}_{(\cdot m)}^{(k \cdot)}\right] ; \\
\left(A_{(m)}^{(k)}\right)_{21}=\kappa^{2} \delta_{(m)}^{(k)}+4\left(1-\beta^{2}\right) D_{(\cdot n)}^{(k \cdot)} \bar{D}_{(\cdot m)}^{(n \cdot)} .
\end{gathered}
$$

The linear constraints (1.9) can be hence formulated for the images $U_{i}^{(k)}$ as follows:

$$
\begin{gathered}
\mathbf{B} \cdot \mathbf{U}=0, \quad \mathbf{B}=\left(\begin{array}{c}
\mathbf{B}_{S} \\
\mathbf{B}_{A}
\end{array}\right)_{4 \times(2 N+2)} ; \\
\mathbf{B}_{S}=\frac{1}{2}\left(\mathbf{B}_{+}+\mathbf{B}_{-}\right), \quad \mathbf{B}_{A}=\frac{1}{2}\left(\mathbf{B}_{+}-\mathbf{B}_{-}\right) ; \\
\mathbf{B}_{ \pm}=\left(\begin{array}{cc}
i \kappa\left(\beta^{-2}-2\right) \delta_{(n)}^{(k)} p_{(k)}^{ \pm} & \beta^{-2} \bar{D}_{(n)}^{(\urcorner k)} p_{(k)}^{ \pm} \\
\bar{D}_{(n\urcorner)}^{(k k)} p_{(k)}^{ \pm} & i \kappa \delta_{(n)}^{(k)} p_{(k)}^{ \pm}
\end{array}\right)
\end{gathered}
$$

Here the symmetry conditions for the constraints are taken into account. Considering hence for (1.13), (1.14), we obtain the solution of the constrained stationary values problem for two quadratic forms $\mathbf{A}$ and $\mathbf{I}$ accordingly to [48]:

$$
\mathbf{U}^{\mathrm{T}} \cdot \mathbf{A} \cdot \mathbf{U} / \mathbf{U} \cdot \mathbf{U}=0, \quad \mathbf{B} \cdot \mathbf{U}=0 .
$$

Following [48], let us introduce the QZ decomposition for the constraint matrix (1.13)

$$
\mathbf{Q}^{\mathrm{T}} \cdot \mathbf{B}^{\mathrm{T}} \cdot \mathbf{Z}=\left(\begin{array}{ll}
\mathbf{S} & \mathbf{0} \\
\mathbf{0} & \mathbf{0}
\end{array}\right)_{(2 N+2) \times 4},
$$

As a result, we obtain the following operator accounting for the constraints (1.13):

$$
\begin{gathered}
\mathbf{A}_{C}=\mathbf{Q}^{\mathrm{T}} \cdot \mathbf{A} \cdot \mathbf{Q}, \\
\mathbf{A}_{C}=\left(\begin{array}{ll}
\overline{\mathbf{A}}_{11} & \overline{\mathbf{A}}_{12} \\
\overline{\mathbf{A}}_{21} & \overline{\mathbf{A}}_{22}
\end{array}\right)_{(2 N+2) \times(2 N+2)}
\end{gathered}
$$

and the stationary values for $(1.15)$ can be found from the unconstrained problem:

$$
\left(\overline{\mathbf{A}}_{22}-\omega^{2} \mathbf{I}\right) \cdot \mathbf{V}=0, \quad \mathbf{V}=\mathbf{Q}^{\mathrm{T}} \cdot \mathbf{U}
$$

The spectrum of the system consists in two subspectra $S$ and $A$ corresponding to the longitudinal and bending waves in the layer:

$$
\begin{gathered}
S: k, m=\{2 n, N+2 n\} ; \\
A: k, m=\{2 n-1, N+2 n-2\}, \\
n \in\left[0,\left[\frac{1}{2}(N-1)\right]\right] \cup \mathrm{Z} .
\end{gathered}
$$

The waveforms can be defined hence in terms of the Nth order plate theory as follows [37]:

$$
\begin{gathered}
u_{\alpha}^{n}(\zeta)=U_{\alpha}^{k n} p_{(k)}(\zeta), \\
\alpha=1,2, \quad k=0 \ldots N-1, \quad n=1 \ldots N ; \\
\mathbf{U}^{m}=\mathbf{Q} \cdot\left\lfloor V_{1}^{k m} \quad V_{2}^{k m}\right], \quad m \in[1,2 N-2] \cap Z .
\end{gathered}
$$


On the Use of Extended Plate Theories of Vekua - Amosov Type for Wave Dispersion Problems

\section{CONVERGENCY ANALYSIS}

Accordingly to [37-42], let us use Legendre polynomials as expansion functions $p_{(k)}(\zeta)$. The locking phase frequencies computed as stationary values of the problem (1.15), or the eigenvalues for the spectral problem (1.18) at $\kappa \rightarrow 0$, are presented below in the Table 1 and Table 2 for longitudinal and bending waves respectively.

Table 1. Convergence of dimensionless locking frequencies of longitudinal waves to the RayleighLamb problem solution.

\begin{tabular}{|l|c|c|c|c|c|c|c|c|c|c|}
\hline $\mathrm{N}$ & 1 & 2 & 3 & 4 & 5 & 6 & 7 & 8 & 9 & 10 \\
\hline 2 & 0.00 & - & - & - & - & - & - & - & - & - \\
\hline 3 & 0.00 & 1.89 & - & - & - & - & - & - & - & - \\
\hline 4 & 0.00 & 1.89 & 1.97 & - & - & - & - & - & - & - \\
\hline 5 & 0.00 & 1.91 & 1.98 & 5.68 & - & - & - & - & - & - \\
\hline 6 & 0.00 & 1.91 & 2.00 & 4.03 & 5.68 & - & - & - & - & - \\
\hline 7 & 0.00 & 1.91 & 2.00 & 4.03 & 5.74 & 9.83 & - & - & - & - \\
\hline 8 & 0.00 & 1.91 & 2.00 & 4.02 & 5.73 & 6.37 & 9.82 & - & - & - \\
\hline 9 & 0.00 & 1.91 & 2.00 & 4.02 & 5.72 & 6.37 & 9.64 & 14.67 & - & - \\
\hline 10 & 0.00 & 1.91 & 2.00 & 4.00 & 5.72 & 6.11 & 9.13 & 9.64 & 14.67 & - \\
\hline 11 & 0.00 & 1.91 & 2.00 & 4.00 & 5.72 & 6.11 & 9.13 & 9.51 & 13.73 & 20.40 \\
\hline 12 & 0.00 & 1.91 & 2.00 & 4.00 & 5.72 & 6.00 & 8.35 & 9.52 & 12.40 & 13.73 \\
\hline 13 & 0.00 & 1.91 & 2.00 & 4.00 & 5.72 & 6.00 & 8.35 & 9.53 & 12.40 & 13.32 \\
\hline 14 & 0.00 & 1.91 & 2.00 & 4.00 & 5.72 & 6.00 & 8.00 & 9.53 & 10.84 & 13.32 \\
\hline 15 & 0.00 & 1.91 & 2.00 & 4.00 & 5.72 & 6.00 & 8.00 & 9.53 & 10.84 & 13.34 \\
\hline 16 & 0.00 & 1.91 & 2.00 & 4.00 & 5.72 & 6.00 & 8.00 & 9.53 & 10.05 & 13.34 \\
\hline \hline Ex. & 0.00 & 1.91 & 2.00 & 4.00 & 5.72 & 6.00 & 8.00 & 9.53 & 10.00 & 12.00 \\
\hline
\end{tabular}

Table 2. Convergence of dimensionless locking frequencies of bending waves to the Rayleigh-Lamb problem solution.

\begin{tabular}{|l||c|c|c|c|c|c|c|c|c|c|}
\hline $\mathrm{N}$ & 1 & 2 & 3 & 4 & 5 & 6 & 7 & 8 & 9 & 10 \\
\hline 2 & 0.00 & - & - & - & - & - & - & - & - & - \\
\hline 3 & 0.00 & 0.99 & - & - & - & - & - & - & - & - \\
\hline 4 & 0.00 & 0.99 & 3.77 & - & - & - & - & - & - & - \\
\hline 5 & 0.00 & 1.00 & 2.98 & 3.77 & - & - & - & - & - & - \\
\hline 6 & 0.00 & 1.00 & 2.98 & 3.82 & 7.68 & - & - & - & - & - \\
\hline 7 & 0.00 & 1.00 & 3.00 & 3.81 & 5.16 & 7.68 & - & - & - & - \\
\hline 8 & 0.00 & 1.00 & 3.00 & 3.81 & 5.16 & 7.67 & 12.14 & - & - & - \\
\hline 9 & 0.00 & 1.00 & 3.00 & 3.81 & 5.06 & 7.67 & 7.70 & 12.14 & - & - \\
\hline 10 & 0.00 & 1.00 & 3.00 & 3.81 & 5.06 & 7.62 & 7.70 & 11.65 & 17.41 & - \\
\hline 11 & 0.00 & 1.00 & 3.00 & 3.81 & 5.00 & 7.20 & 7.62 & 10.70 & 11.65 & 17.41 \\
\hline 12 & 0.00 & 1.00 & 3.00 & 3.81 & 5.00 & 7.20 & 7.62 & 10.70 & 11.41 & 15.92 \\
\hline 13 & 0.00 & 1.00 & 3.00 & 3.81 & 5.00 & 7.00 & 7.62 & 9.56 & 11.41 & 14.21 \\
\hline 14 & 0.00 & 1.00 & 3.00 & 3.81 & 5.00 & 7.00 & 7.62 & 9.56 & 11.42 & 14.21 \\
\hline 15 & 0.00 & 1.00 & 3.00 & 3.81 & 5.00 & 7.00 & 7.62 & 9.00 & 11.42 & 12.19 \\
\hline
\end{tabular}




\begin{tabular}{|c|c|c|c|c|c|c|c|c|c|c|}
\hline $\mathrm{N}$ & 1 & 2 & 3 & 4 & 5 & 6 & 7 & 8 & 9 & 10 \\
\hline \hline 16 & 0.00 & 1.00 & 3.00 & 3.81 & 5.00 & 7.00 & 7.62 & 9.00 & 11.41 & 12.19 \\
\hline Ex. & 0.00 & 1.00 & 3.00 & 3.81 & 5.00 & 7.00 & 7.62 & 9.00 & 11.00 & 11.43 \\
\hline
\end{tabular}

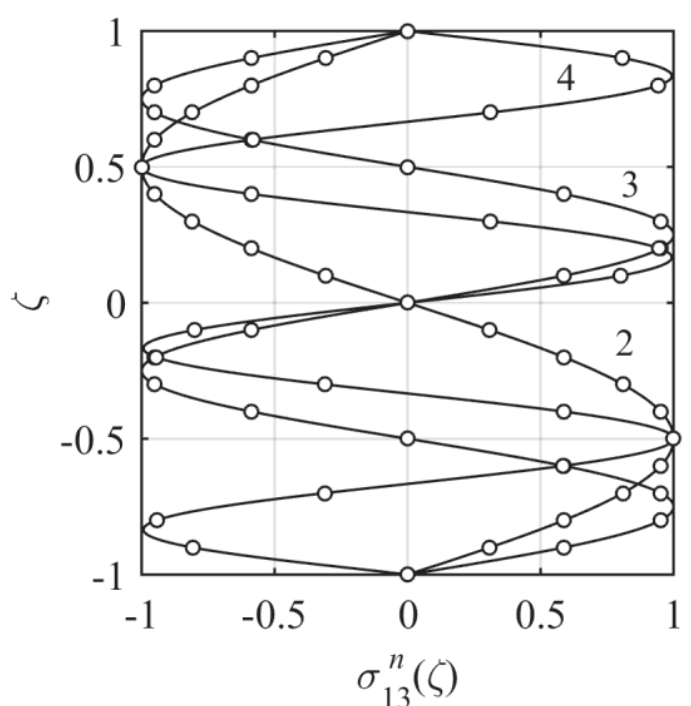

(a)

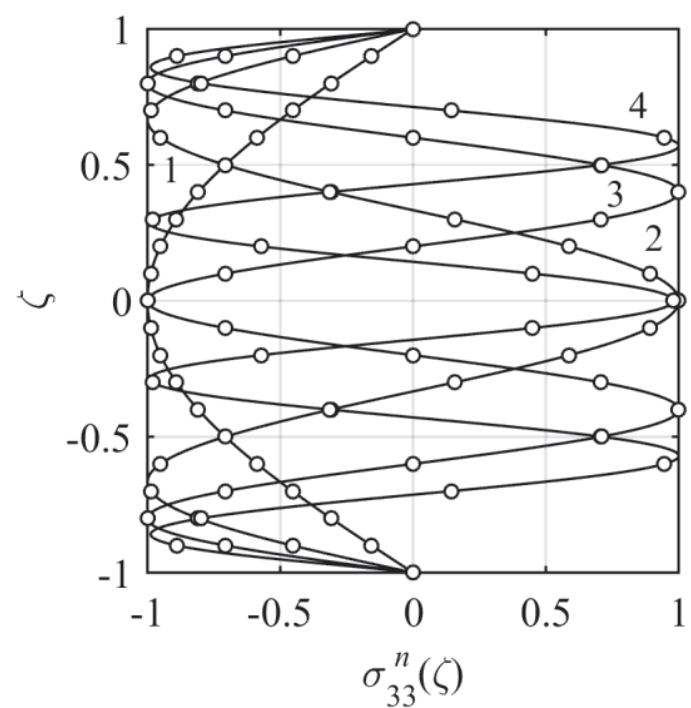

(b)

Figure 1. Normal waveforms of longitudinal waves: exact solution [36] (solid line), plate theory of $15^{\text {th }}$ order (dots).

The approximate solutions given by the extended plate theories converge to the exact solutions of the three-dimensional RayleighLamb problem [36] at the orders shown in the Table 3 (the convergence is estimated by the relative error computed at $\kappa \rightarrow 0$ as follows:

$$
\left(\omega_{0}-\omega_{0 L}\right) / \omega_{0 L} \leq 0,05 \text {. }
$$

Table 3. The approximate solutions by the extended plate theories at various orders.

\begin{tabular}{|l|l|l|l|l|l|l|l|l|}
\hline$n$ & 2 & 3 & 4 & 5 & 6 & 7 & 8 & 9 \\
\hline \multicolumn{8}{|c|}{ Longitudinal modes } \\
\hline$N$ & 3 & 3 & 4 & 6 & 6 & 10 & 10 & 16 \\
\hline \multicolumn{8}{|c|}{ Bending modes } \\
\hline$N$ & 3 & 5 & 5 & 9 & 11 & 9 & 15 & 12 \\
\hline
\end{tabular}

Let us compute the stress profiles corresponding to the approximate wave forms obtained from the plate theory of Nth order:

$$
\begin{gathered}
\sigma_{13}^{n}(\zeta)=\left\lfloor\bar{D}_{(m)}^{((k)} U_{1}^{m n}+i \kappa U_{3}^{k n}\right\rfloor p_{(k)}(\zeta) ; \\
\sigma_{33}^{n}(\zeta)=\left[i \kappa\left(\beta^{-2}-2\right) U_{1}^{k n}+\beta^{-2} \bar{D}_{(m-)}^{(k)} U_{3}^{m n}\right] p_{(k)}(\zeta) .
\end{gathered}
$$

The normalized stress forms corresponding to longitudinal waves are shown on the Figure 1. It can be seen that for all stress profiles the homogeneous boundary condition on the faces of the layer are satisfied exactly.

\section{CONCLUSIONS}

The solution of the wave dispersion problem for the plane elastic layer is obtained on the background of the extended plate theory of $\mathrm{N}^{\text {th }}$ order. This theory allows the exact satisfaction of the boundary conditions on the faces of the layer, thus, the wave reflection condition on the faces is secured. The convergence of the approximate locking phase frequencies to the exact ones following from the solution of the 
three-dimensional Rayleigh-Lamb problem is shown.

\section{ACKNOWLEDGEMENTS}

This investigation was performed as a part of the State Task for Basic Researches GP 14 (0050-2017-0001), state register number AAAA-A17-117032010136-3.

\section{REFERENCES}

1. Grigolyuk E.I., Selezov I.T. Non-Classical Theories for Beams, Plates, and Shells Oscillations. // Outcomes of Science and Technology: Mechanics of Deformable Solids. - VINITI, Moscow, 1973, 272 pages.

2. Carrera E. A Study of Transverse Normal Stress Effect on Vibration of Multilayered Plates and Shells // J. Sound \& Vibration, Vol. 225, 1999, pp. 803-829.

3. Batra R.C., Aimmanee S. Vibrations of Thick Isotropic Plates with Higher Order Shear and Normal Deformable Plate Theories // Comput. and Struct., Vol. 83, 2005, pp. 934-955.

4. Zhou D., Au F.T.K., Cheung Y.K., Lo S.H. Three-Dimensional Vibration Analysis of Circular and Annular Plates via the Chebyshev-Ritz Method // Int. J. Sol. Struct., Vol. 40, 2003, pp. 3089-3105.

5. Kang Jae-Hoon, Leissa A. W. ThreeDimensional Vibration Analysis of Thick, Complete Conical Shells. // Trans. of ASME, Vol. 71, 2004, pp. 502-507.

6. Carrera E., Brischetto S. Importance of Higher Order Modes and Refined Theories in Free Vibration Analysis of Composite Plates. // J. Applied Math., Vol. 77, 2010, 011013 (14 pp).

7. Carrera E., Zappino E. Carrera Unified Formulation for Free Vibration Analysis of Aircraft Structures // AIAA Journal, Vol. 54, No. 1, 2016, pp. 280-292.
8. Carrera E. Theories and Finite Elements for Multilayered, Anisotropic, Composite Plates and Shells. // Arch. Comput. Methods Eng., 9, 2002, pp. 87-140.

9. Jha D.K., Kant T., Singh R.K. A Critical Review of Recent Research on Functionally Graded Plates. // Composite Struct., Vol. 96, 2013, pp. 833-849.

10. Brischetto S. A General Exact Elastic Shell Solution for Bending Analysis of Functionally Graded Materials. // Composite Struct., Vol. 175, 2017, pp. 70-85.

11. Vel C.C., Batra R.C. Three-Dimensional Exact Solution for the Vibration of Functionally Graded Rectangular Plates // J. Sound \& Vibration, Vol. 272, 2004, pp. 703-730.

12. Sheikholeslami S.A. Saidi A.R. Vibration Analysis of Functionally Graded Rectangular Plates Resting on Elastic Foundation Using Higher-Order Shear and Normal Deformable Plate Theory. // Composite Structures, Vol. 106, 2013, pp. 350-361.

13. Gupta A., Talha M., Singh B.N. Vibration Characteristics of Functionally Graded Material Plate with Various Boundary Constraints Using Higher Order Shear Deformation Theory. // Composites Part B: Engrg., Vol. 94, 2016, pp. 64-74.

14. Gupta A., Talha M. An Assessment of a Non-Polynomial Based Higher Order Shear and Normal Deformation Theory for Vibration Response of Gradient Plates with Initial Geometric Imperfections // Composites Part B: Engrg., Vol. 107, 2016, pp. 141-161.

15. Matsunaga H. Free Vibration and Stability of Functionally Graded Plates According to a 2D Higher-Order Deformation Theory. // Composite Struct., Vol. 82, 2008, pp. 499512.

16. Matsunaga H. Free Vibration and Stability of Functionally Graded Shallow Shells According to a 2D Higher-Order Deformation Theory. // Composite Struct., Vol. 84, 2008, pp.132-146. 
17. Zozulya V.V., Chang Ch. A High Order Theory for Functionally Graded Axisymmetric Cylindrical Shells. // Int. J. Mech. Sci., Vol. 60, 2012, pp. 12-22.

18. Kulikov G.M. Plotnikova S.V. ThreeDimensional Solution of the Free Vibration Problem for Metal-Ceramics shells using the Method of Sampling Surfaces // Mechanics of Composite Materials. Vol. 53(2017). Pp. 31-44.

19. Mehrkash M., Azkari M., Mirdamadi H. R. Reliability Assessment of Different Plate Theories for Elastic Wave Propagation Analysis in Functionally Graded Plates. // Ultrasonics, Vol. 54, 2014, pp. 106-120.

20. Elmaimouni L., Lefebvre J.E., Zhang V., Gryba T. Guided Waves in Radially Graded Cylinders: A Polynomial Approach. // NDT\&E Int., Vol. 38, 2005, pp. 344-353.

21. Yu J., Lefebvre J.E., Guo Y.Q. FreeUltrasonic Waves in Multilayered Plates: An Improvement of the Legendre Polynomial Approach for Multilayered Structures with Very Dissimilar Materials // Composites. Part B: Engrg., Vol. 5, 2013, pp. 260-269.

22. Dahmen S., Ben Amor M., Ben Ghozlen M.H. Investigation of the Coupled Lamb Waves Propagation in Viscoelastic and Anisotropic Multilayer Composites by Legendre Polynomial Method. // Composite Structures, Vol. 153, 2016, pp. 557-568.

23. Zheng M., He C., Lu Y., Wu B. StateVector Formalism and the Legendre Polynomial Solution for Modelling Guided Waves in Anistropic Plates. // J. Sound \& Vibration, Vol. 412, 2018, pp. 372-378.

24. Kaplunov J.D., Kossovich L.Yu., Nolde E.V. Dynamics of Thin-Walled Elastic Bodies. San Diego - London - Boston New York - Sydney - Tokyo - Toronto, Academic Press, 1998.

25. Zernov V., Kaplunov J.D. ThreeDimensional Edge Waves in Plates // Proc. Roy. Soc. Lond. A: Math. Phys. Engrg. Sci., Vol. 464, 2008, pp. 301-318.

26. Wilde M. V. Investigation of the Boundary Resonance Phenomenon in Plates on the
Basis of the 3D Elasticity Theory Equations. // Mech. Deform. Media, Saratov Univ., Issue 16, 2010, pp. 7-14.

27. Wilde M. V. Higher Order Edge Waves in Thick Plates. // Vestn. Lobachevsky Univ. N. Novgorod, Issue 9, 2011, pp. 173-183.

28. Vekua I. N. Shell Theories: General Methods of Construction. Boston, USA, Pitman Adv. Publ. Progr., 1985.

29. Guliaev V.I., Bazhenov B.A., Lizunov P.P. Nonclassical Shell Theory and Applications in Engineering. Lvov, Vishcha Shkola, 1978 (in Russian).

30. Amosov A.A. An Approximate ThreeDimensional Theory of Thick Plates and Shells // Structural Mechanics and Design of Buildings, No. 5, 1987, pp. 37-42.

31. Amosov A.A., Zhavoronok S.I. An Approximate High-Order Theory of Thick Anisotropic Shells. // International Journal of Computational Civil and Structural Engineering, Vol. 1, 2003, pp. 28-38.

32. Volchkov Yu.M., Dergileva L.A. Reducing Three-Dimensional Elasticity Problems to Two-Dimensional Problems by Approximating Stresses and Displacements by Legendre Polynomials. // J. Appl. Mech. Techn. Phys., Vol. 48, 2007, pp. 450-459.

33. Annin B.D., Volchkov Yu.M. Nonclassical models of the theory of plates and shell.s // J. Appl. Mech. Techn. Phys., Vol. 57, 2016, pp. 769-776.

34. Zozulya V.V. A Higher Order Theory for Shells, Plates and Rods // Int. J. Mech. Sci., Vol. 103, 2015, pp. 40-54.

35. Zhavoronok S.I. Variational Equations of a Three-Dimensional Anisotropic Theory of Shells. // Vestn. Lobachevsky Univ. N. Novgorod, Iss. 4-5, 2011, pp. 2154-2156.

36. Grinchenko V.T., Meleshko V.V. Harmonic Oscillations and Waves in Elastic Bodies. Kiev, USSR, Nauk. dumka, 1981.

37. Zhavoronok S.I. Investigation of Harmonic Waves in Elastic Layer Using Nth Order Three-Dimensional Shells' Theory // The Journal of Mekhanika Kompozitsionnykh 
Materialov i Konstruktsii, Vol. 16, 2010, pp. 693-701.

38. Zhavoronok S.I. Investigation of Propagating Modes of Harmonic Waves in Elastic Layer Using Nth Order ThreeDimensional Shell Theory. // The Journal of Mekhanika Kompozitsionnykh Materialov i Konstruktsii, Vol. 17, 2011, pp. 278-287.

39. Zhavoronok S.I. Kinematics of Normal Modes in Elastic Layer for Some Wavenumbers Investigation Based on Nth Order Three Dimensional Shells Theory. // The Journal of Mekhanika Kompozitsionnykh Materialov Konstruktsii, Vol. 18, 2012, pp. 45-56.

40. Zhavoronok S.I. A Formulation of the Three-Dimensional Approximated Shells Theory of Nth Order Using Generalized Displacements and its Application to Steady Dynamics. // The Journal of Mekhanika Kompozitsionnykh Materialov i Konstruktsii, Vol. 18, 2012, pp. 333-344.

41. Egorova O.V., Kurbatov A.S., Zhavoronok S.I. An Application of Various N'th Order Shell Theories to Normal Waves Propagation problems. // Proc. Tula State Univ., Vol. 11, 2014, pp. 255-266.

42. Egorova O.V., Kurbatov A.S., Zhavoronok S.I. The Variational Equations of the Extended N'th Order Shell Theory and its Application to Some Problems of Dynamics. // PNPU Mech. Bulletin, No. 2, 2015, pp. 36-59.

43. Zhavoronok S.I., Leontiev A.N., Leontiev K.A. Analysis of Thick-Walled Rotation Shells Based on the Legendre Polynomials. // International Journal for Computational Civil and Structural Engineering, Vol. 6, 2010, pp. 105-111.

44. Zhavoronok S.I. On the Variational Formulation of the Extended Thick Anisotropic Shells Theory of I.N. Vekua Type // Procedia Enginering, Vol. 111, 2015, pp. 888-895.

45. Zhavoronok S.I. The Generalized Lagrange Equations of the Second Kind for the Extended Three-Dimensional Nth Order
Theory of Anisotropic Shells // The Journal of Mekhanika Kompozitsionnykh Materialov i Konstruktsii, Vol. 21, 2015, pp. 370-381.

46. Zhavoronok S.I. The Extended Shell Theory of Vekua-Amosov Type and the Low-Order Plate Models // International Journal for Computational Civil and Structural Engineering, Vol. 12, 2016, pp. 27-35.

47. Zhavoronok S.I. A General Higher-Order Shell Ttheory Based on the Analytical Dynamics of Constrained Continuum Systems. // Shell Structures: Theory and Applications, Vol. 4. CRC Press / Balkema, Taylor \& Francis Gr., Leiden, 2017, pp. 189-192.

48. Golub G.H., Underwood R. Stationary Values of the Ratio of Quadratic Forms Subject to Linear Constraints // ZAMP, Vol. 21, 1970, pp. 318-326.

49. Zhavoronok S.I. On Hamiltonian Formulations and Conservation Laws for Plate Theories of Vekua-Amosov Type // International Journal for Computational Civil and Structural Engineering, 13, 2017, pp. 82-95.

\section{СПИСОК ЛИТЕРАТУРЫ}

1. Григолюк Э.И. Селезов И.Т. Неклассические теории колебаний стержней пластин и оболочек. - М.: ВИНИТИ, 1973. - 272 с.

2. Carrera E. A Study of Transverse Normal Stress Effect on Vibration of Multilayered Plates and Shells // J. Sound \& Vibration, Vol. 225, 1999, pp. 803-829.

3. Batra R. C., Aimmanee S. Vibrations of Thick Isotropic Plates with Higher Order Shear and Normal Deformable Plate Theories // Comput. and Struct., Vol. 83, 2005, pp. 934-955.

4. Zhou D., Au F.T.K., Cheung Y.K., Lo S.H. Three-Dimensional Vibration Analysis of Circular and Annular Plates via the 
Chebyshev-Ritz Method // Int. J. Sol. Struct., Vol. 40, 2003, pp. 3089-3105.

5. Kang Jae-Hoon, Leissa A. W. ThreeDimensional Vibration Analysis of Thick, Complete Conical Shells. // Trans. of ASME, Vol. 71, 2004, pp. 502-507.

6. Carrera E., Brischetto S. Importance of Higher Order Modes and Refined Theories in Free Vibration Analysis of Composite Plates. // J. Applied Math., Vol. 77, 2010, 011013 (14 pp).

7. Carrera E., Zappino E. Carrera Unified Formulation for Free Vibration Analysis of Aircraft Structures // AIAA Journal, Vol. 54, No. 1, 2016, pp. 280-292.

8. Carrera E. Theories and Finite Elements for Multilayered, Anisotropic, Composite Plates and Shells. // Arch. Comput. Methods Eng., 9, 2002, pp. 87-140.

9. Jha D.K., Kant T., Singh R.K. A Critical Review of Recent Research on Functionally Graded Plates. // Composite Struct., Vol. 96, 2013, pp. 833-849.

10. Brischetto S. A General Exact Elastic Shell Solution for Bending Analysis of Functionally Graded Materials. // Composite Struct., Vol. 175, 2017, pp. 70-85.

11. Vel C.C., Batra R.C. Three-Dimensional Exact Solution for the Vibration of Functionally Graded Rectangular Plates // J. Sound \& Vibration, Vol. 272, 2004, pp. 703-730.

12. Sheikholeslami S.A. Saidi A.R. Vibration Analysis of Functionally Graded Rectangular Plates Resting on Elastic Foundation Using Higher-Order Shear and Normal Deformable Plate Theory. // Composite Structures, Vol. 106, 2013, pp. 350-361.

13. Gupta A., Talha M., Singh B.N. Vibration Characteristics of Functionally Graded Material Plate with Various Boundary Constraints Using Higher Order Shear Deformation Theory. // Composites Part B: Engrg., Vol. 94, 2016, pp. 64-74.

14. Gupta A., Talha M. An Assessment of a Non-Polynomial Based Higher Order Shear and Normal Deformation Theory for Vibration Response of Gradient Plates with Initial Geometric Imperfections // Composites Part B: Engrg., Vol. 107, 2016, pp. 141-161.

15. Matsunaga H. Free Vibration and Stability of Functionally Graded Plates According to a 2D Higher-Order Deformation Theory. // Composite Struct., Vol. 82, 2008, pp. 499512.

16. Matsunaga H. Free Vibration and Stability of Functionally Graded Shallow Shells According to a 2D Higher-Order Deformation Theory. // Composite Struct., Vol. 84, 2008, pp.132-146.

17. Zozulya V.V., Chang Ch. A High Order Theory for Functionally Graded Axisymmetric Cylindrical Shells. // Int. J. Mech. Sci., Vol. 60, 2012, pp. 12-22.

18. Kulikov G.M. Plotnikova S.V. ThreeDimensional Solution of the Free Vibration Problem for Metal-Ceramics shells using the Method of Sampling Surfaces // Mechanics of Composite Materials. Vol. 53(2017). Pp. 31-44.

19. Mehrkash M., Azkari M., Mirdamadi H. R. Reliability Assessment of Different Plate Theories for Elastic Wave Propagation Analysis in Functionally Graded Plates. // Ultrasonics, Vol. 54, 2014, pp. 106-120.

20. Elmaimouni L., Lefebvre J.E., Zhang V., Gryba T. Guided Waves in Radially Graded Cylinders: A Polynomial Approach. // NDT\&E Int., Vol. 38, 2005, pp. 344-353.

21. Yu J., Lefebvre J.E., Guo Y.Q. FreeUltrasonic Waves in Multilayered Plates: An Improvement of the Legendre Polynomial Approach for Multilayered Structures with Very Dissimilar Materials // Composites. Part B: Engrg., Vol. 5, 2013, pp. 260-269.

22. Dahmen S., Ben Amor M., Ben Ghozlen M.H. Investigation of the Coupled Lamb Waves Propagation in Viscoelastic and Anisotropic Multilayer Composites by Legendre Polynomial Method. // Composite Structures, Vol. 153, 2016, pp. 557-568. 
23. Zheng M., He C., Lu Y., Wu B. StateVector Formalism and the Legendre Polynomial Solution for Modelling Guided Waves in Anistropic Plates. // J. Sound \& Vibration, Vol. 412, 2018, pp. 372-378.

24. Kaplunov J.D., Kossovich L.Yu., Nolde E.V. Dynamics of Thin-Walled Elastic Bodies. San Diego - London - Boston New York - Sydney - Tokyo - Toronto, Academic Press, 1998.

25. Zernov V., Kaplunov J.D. ThreeDimensional Edge Waves in Plates // Proc. Roy. Soc. Lond. A: Math. Phys. Engrg. Sci., Vol. 464, 2008, pp. 301-318.

26. Вильде М.В. Исследование явления краевого резонанса в пластинах на основе трехмерных уравнений теории упругости. // Механика деформируемых сред, 2010, №16, c. 7-14.

27. Вильде М.В. Кромочные волны высшего порядка в толстой пластине. // Вестник Нижегородского университета им. Н.И. Лобачевского, 2011, №4-5, с. 2060-2062.

28. Vekua I.N. Shell Theories: General Methods of Construction. Boston, USA, Pitman Adv. Publ. Progr., 1985.

29. Гуляев В.И., Баженов В.А., Лизунов П.П. Неклассическая теория оболочек и ее приложение к решению инженерных задач. - Львов: Вища школа, 1978.- 192 с.

30. Амосов А.А. Приближенная трехмерная теория толстостенных пластин и оболочек. // Строительная механика и расчет сооружений, №5, 1987, с. 37-42.

31. Amosov A.A., Zhavoronok S.I. An Approximate High-Order Theory of Thick Anisotropic Shells. // International Journal of Computational Civil and Structural Engineering (Международный журнал по расчету гражданских и строительных конструкций), Vol. 1, 2003, pp. 28-38.

32. Volchkov Yu.M., Dergileva L.A. Reducing Three-Dimensional Elasticity Problems to Two-Dimensional Problems by Approximating Stresses and Displacements by Legendre Polynomials. // J. Appl. Mech. Techn. Phys., Vol. 48, 2007, pp. 450-459.
33. Annin B.D., Volchkov Yu.M. Nonclassical models of the theory of plates and shell.s // J. Appl. Mech. Techn. Phys., Vol. 57, 2016, pp. 769-776.

34. Zozulya V.V. A Higher Order Theory for Shells, Plates and Rods // Int. J. Mech. Sci., Vol. 103, 2015, pp. 40-54.

35. Жаворонок С.И. Вариационные уравнения трехмерной теории анизотропных оболочек. /// Вестник Нижегородского университета им. Н.И. Лобачевского, 2011, №4-5, с. 2154-2156.

36. Гринченко В.T., Мелешко В.B. Гармонические колебания и волны в упругих телах. - Киев: Наукова Думка, 1981. - $284 \mathrm{c}$.

37. Жаворонок С.И. Исследование гармонических волн в упругом слое на основе трехмерной теории оболочек $\mathrm{N}$-го порядка. // Механика композиционных материалов и конструкций, 2010, Том 16, №5, c. 693-701.

38. Жаворонок С.И. Исследование распространяющихся мод гармонических волн в упругом слое на базе трехмерной теории оболочек N-го порядка. // Механика композиционных материалов и конструкций, 2011, Том 17, №2, с. 278287.

39. Жаворонок С.И. Исследование кинематики нормальных волн в упругом слое на основе трехмерной теории оболочек $\mathrm{N}$-го порядка для различных значений волновых чисел. // Механика композиционных материалов и конструкций, 2012, Том 18, №1, с. 45-56.

40. Zhavoronok S.I. A Formulation of the Three-Dimensional Approximated Shells Theory of Nth Order Using Generalized Displacements and its Application to Steady Dynamics. // Механика композиционных материалов и конструкций, 2012, Том 18, №3, с. 333-344.

41. Егорова О.В., Жаворонок С.И., Курбатов А.С. О приложении различных вариантов теории оболочек $\mathrm{N}$-го порядка к некоторым задачам о прогрессивных 
волнах. // Известия Тульского государственного университета. Технические науки, 2014, №11-1, с. 255266.

42. Егорова О.В., Жаворонок С.И., Курбатов А.С. О вариационных уравнениях расширенной теории $\mathrm{N}$-го порядка упругих оболочек и их приложении к некоторым задачам динамики. // Вестник Пермского национального исследовательского политехнического университета. Механика, 2015, №2, с. 36-59.

43. Zhavoronok S.I., Leontiev A.N., Leontiev K.A. Analysis of Thick-Walled Rotation Shells Based on the Legendre Polynomials. // International Journal for Computational Civil and Structural Engineering (Международный журнал по расчету гражданских и строительных конструкций), Vol. 6, 2010, pp. 105-111.

44. Zhavoronok S.I. On the Variational Formulation of the Extended Thick Anisotropic Shells Theory of I.N. Vekua Type // Procedia Enginering, Vol. 111, 2015, pp. 888-895.

45. Жаворонок С.И. Обобщенные уравнения Лагранжа второго рода расширенной трехмерной теории $\mathrm{N}$-го порядка анизотропных оболочек. // Механика композиционных материалов и конструкций, 2015, Том 21, №3, с. 370381.

46. Zhavoronok S.I. The Extended Shell Theory of Vekua-Amosov Type and the Low-Order Plate Models // International Journal for Computational Civil and Structural Engineering (Международный журнал по расчету гражданских и строительных конструкций), Vol. 12, 2016, pp. 27-35.

47. Zhavoronok S.I. A General Higher-Order Shell Ttheory Based on the Analytical Dynamics of Constrained Continuum Systems. // Shell Structures: Theory and Applications, Vol. 4. CRC Press / Balkema,
Taylor \& Francis Gr., Leiden, 2017, pp. 189-192.

48. Golub G.H., Underwood R. Stationary Values of the Ratio of Quadratic Forms Subject to Linear Constraints // ZAMP, Vol. 21, 1970, pp. 318-326.

49. Zhavoronok S.I. On Hamiltonian Formulations and Conservation Laws for Plate Theories of Vekua-Amosov Type // International Journal for Computational Civil and Structural Engineering (Международный журнал по расчету гражданских и строительных конструкций), 13, 2017, pp. 82-95.

Zhavoronok Sergey Igorevich, Ph.D., Senior researcher of the Department of Mechanics of Smart and Composite Materials and Systems, Institute of Applied Mechanics of Russian Academy of Sciences (IAM RAS); Associate Professor of the Department of Strength of Materials, Machine Dynamics and Strength, Moscow Aviation Institute (National Research University) - MAI. Post Address: Leningradskiy Prospekt 7, 125040, Moscow, Russia, IAM RAS; phone: +7(495) 941-1777;

+7(916) 134-2843;

E-mail: Zhavoronok@iam.ras.ru, zhavor71@mail.ru

Жаворонок Сергей Игоревич, кандидат физикоматематических наук, старший научный сотрудник, Институт прикладной механики Российской академии наук (ИПРИМ РАН); доцент кафедры сопротивления материалов, Московский авиационный институт (национальный исследовательский университет); 125 040, г. Москва, Ленинградский проспект, д. 7, стр. 1; тел. +7(495) 941-1777; +7(916) 134-2843.

E-mail: Zhavoronok@iam.ras.ru, zhavor71@mail.ru 